individual and the group or nation in which he has his being, and vitally affecting the performance of his function as a free member of a free societyproblems of personal and social hygiene, education, food supply and an innumerable host of others upon which scientific workers have long been engaged and which still engage their thought even amid the preoccupations of war. In the field of the relations of national groups President Roosevelt's Aid-for-Democracies Bill has already paved the way for the lines of future inquiry and research. The vast range of inquiry into the conditions of ultimate security for humanity will draw upon the resources of all sciences, and not upon the biological and social sciences only.

\section{New President of the American Association}

Dr. Irving Langmuir, who has been elected president of the American Association for the Advancement of Science, is a well-known figure in international science, and has interested himself particularly in borderline fields extending between physics and chemistry. Early work by Langmuir on the adsorption and reactions of gases at solid surfaces proved to be of fundamental importance to an understanding of many of the phenomena of colloid chemistry, heterogeneous catalysis, surface tension, and even of such an apparently unrelated subject as thermionic emission. One everyday consequence of this work was the gas-filled electric lamp. Arising out of these investigations came the conception of the orientated monolayer as the state of material at phase boundaries, a view which has led to important advances of our knowledge of the mechanism of lubrication of metal surfaces, and of the structure of oil films on liquid surfaces. In 1938 he visited Great Britain as the first American to deliver the Pilgrim Trust Lecture before the Royal Society when he gave a characteristically informative and fascinating account of his views on the structure of protein films (see Nature, December 17, 1938); and he also delivered the Faraday Lecture of the Chemical Society, when he dealt with monolayers on solids. Dr. Langmuir received the Nobel Prize for chemistry for 1932 and was elected a foreign member of the Royal Society in 1935.

\section{Manchester Literary and Philosophical Society:} Air Raid Damage

Tнe Manchester Literary and Philosophical Society lost its historic home, library and Dalton and Joule memorials in an air raid through the spread of a fire from warehouses. In the eighteenth century, when those who could not subscribe to the articles of the Anglican Church were excluded from the universities, academies were founded in several places, that at Manchester being a specially important one. Among the intellectual leaders of the time were Dr. Thomas Percival, a medical pioneer, and Joseph Priestley; and one of the teachers employed by the academy wás John Dalton. A group meeting at Dr. Percival's house founded the Literary and Philosophical Society in 1781, and it met shortly afterwards for a time in the room attached to the non-subscribing chapel in Cross Street, which has also been burnt out. A little later the Society acquired the fine Georgian house which it has now lost, and, in that house, Dalton did his scientific work. A great deal of his apparatus and many of his notes had been placed in the basement to diminish risks, but the fury of the fire destroyed nearly everything. Dalton's watch, Joule's chronometer, some of Dalton's notes and a few small pieces of apparatus have been found and salved.

The Society has also lost, at least for a time, an income it has long received from a trust established on its behalf. In spite of these misfortunes of war, it is maintaining its activities and is asking the cultural societies of Manchester to take part in a co-operative effort for a common home warthy of the long tradition of scientific leadership associated with the names of Dalton, Joule and many later workers belonging to what is believed to be the next oldest learned society in England after the Royal Society.

\section{The Science Museum : Air Raid Damage}

The Science Museum has suffered damage by bombs during air raids on London. A number of bombs have fallen in the vicinity of the Museum, and although the building has suffered from the loss of windows, little damage has resulted to the collections. In one attack practically all the windows on one side of the building were broken, as well as many of the roof lights. Fortunately, the damage sustained by the Museum collections is slight, although a number of exhibition cases in certain galleries have been damaged by blast. Although the Museum is closed to the public, the Science Library continues to remain open, and to afford the usual facilities to readers and borrowers.

\section{The Respirator in an Emergency}

The Prime Minister and the Lord Privy Seal have both recently referred to the possible use of poison gas by the enemy. Although expressly forbidden at the Geneva Convention signed by all the powers, there are indications that make it highly desirable that the people at large shall take heed of the possibility, and review their individual and personal protection against this most horrible form of attack. Everybody has been provided by the State with an efficient gas mask or respirator; it is a simple matter to see that it is in good order and is instantly available at all times. It is not enough, however, to carry the respirator; the owner should practise frequently taking it out of the case and putting it on, holding his breath in the meantime so that the operation becomes a matter of routine which can be done in a few seconds. The respirator should be worn for periods up to twenty minutes, so that one's behaviour in it becomes perfectly normal and the original nervous feeling is forgotten.

Only after such practice does the respirator become part of oneself, and its wearing a matter of instinct in an emergency. If a person is so unfortunate as to be near a bomb containing a lethal non-persistent 
gas when it falls, his death or survival is a question of how few seconds it takes to put on the mask. The cloud of gas is very deadly for some hundreds of yards down a street in the direction of the wind, the length of the most dangerous zone being greatest in narrow streets. Further, everyone should have a clearly thought-out plan in their minds what they are going to do should they encounter gas; this will have to be varied according to circumstances. For example, if they are splashed with a few drops of liquid blister gas the time available to prevent a bad burn is short-a matter of five minutes. A clear plan to enter the first house, drop clothing on the doorstep and wash vigorously with soap and warm water, will prevent them becoming a casualty.

The respirator as a filter of poisoned air depends on the outstanding property of suitably activated charcoal to absorb organic vapours: the charcoal is supplemented by a pad able to hold back the finest particles of dispersed substances. The respirator is the result of prolonged study by experts, aided by the leading men of science. It is an all-purposes defensive weapon as nearly perfect as anything which is mass-produced in such enormous numbers can be. It is carefully tested in the course of manufacture, and is considered to give full protection against any war gases in the concentrations in which they are likely to be encountered by a civilian. It is not exhausted by a single encounter with gas, but should continue effective for many months. It may well be that when a respirator is put on in gas, and however quickly, it will enclose a little of the gas, which will cause irritation during the first minute or so. The impulse to tear off the mask must be resisted; also the thought that the mask is not fitting or the filter is letting gas pass. Previous practice will have proved this thought to be wrong, and very soon the respirator will be comfortable. We can do nothing when a high explosive bomb falls near; we can save our homes if we are quick when incendiary bombs fall on them; we can defeat a gas attack if we have trained ourselves in doing it.

\section{Preparation of Fine Chemicals}

The Advisory Research Council of the Chemical Society, in collaboration with the Association of British Chemical Manufacturers, is putting into operation a scheme for organizing the preparation of fine chemicals in Great Britain by part-time volunteer workers in the laboratories of universities, technical colleges, and other institutions. It is essential to the scheme that compounds so prepared must be required for work of national importance and be not available commercially, and that the manufacturers of fine chemicals are themselves unable, or do not find it convenient, to meet the demands. It is intended that preparations should be carried out on a costprice basis which would include charges for materials, gas, electricity, etc., but not for the workers' services. No profits of any kind will be permitted. Those who wish their names to be added to the list of volunteer helpers in connexion with this scheme should communicate with the General Secretary, Chemical
Society, Piccadilly, London, W.1, to whom inquiries for fine chemicals falling within the scope of the scheme may also be made.

\section{Issues and Parties in India}

AN English resident in the Punjab writes taking exception to views expressed in these columns in a reference to Mr. L. S. Amery's review of the political situation in India in August last (see NATURE, 146. $255 ; 1940)$. He points out that while it is true that there are differences among the Indians themselves, all parties are at one in desiring Home Rule. To attain Home Rule is, or is supposed to be, the purpose of the Indian National Congress; and the preponderancy of the Hindu community in it merely reflects the fact that Hindus are a large majority in the country. It is stated that Moslems are by no means all anti-Nationalist or anti-Congress, and in fact only one party of them is so--the Moslem League, a reactionary conservative body composed of big landlords, title-holders and the like. Indeed, he adds, if a straight vote could be taken without confusing the issue by an appeal to communal fanaticism through such cries as "religion in danger", it is very doubtful if the Moslem League would have a majority over the combined votes of progressive Moslem parties. It was in fact decisively defeated in the last elections in the four provinces which have Moslem majorities. As for the Princes, they are, he says, a relic of feudalism, and do not represent their people. Although Mr. Amery's last offer, having regard to the conditions, was not so bad, it encouraged minorities to believe that however fantastic their claims, the British Government would support them, or at least allow them to hold up Home Rule indefinitely, thus lending colour to the Indian view that Britain does not really mean to give up her power and is playing the game of "divide and rule".

While it is desirable to place on record such a view of the facts of the situation in India in the interest of clearer understanding, it by no means must be held to imply assent among a people with whom religious belief and ritual is all-powerful as in India. The admission that successful opposition to the National Moslem League would depend upon the absence of an appeal to communal fanaticism, demands disruption of the social and religious functions of the individual member of a community in everyday life which is opposed to the whole of Indian culture and tradition. No doubt in many of the more progressive among the people of India, this tradition has become weaker, but nevertheless even among them it persists in some degree. It is for this among other reasons that competent observers have doubted the wisdom or even the possibility of applying the democratic ideal to Indian conditions. On this account, and not with the view of delaying Home Rule by fomenting intercommunal differences, the British Government has sought to accustom Indian ways of thought to respect for the rights of the individual through a compromise which, for the time being, appears to lay undue stress upon the claims of minorities. 